\title{
Permeable Pavers Designed for Rapid Renewal by Considering Sweeper Mechanics: Initial Field Tests
}

\author{
William James, ${ }^{1}$ Harald von Langsdorff ${ }^{2}$ and Michael McIntyre ${ }^{3}$ \\ ${ }^{1}$ CHI, Guelph, Ontario; ${ }^{2}$ F. Von Langsdorff Licensing Limited, Caledon, Ontario; ${ }^{3}$ Unilock, Acton, Ontario.
}

\begin{abstract}
Previous publications on restoring clogged permeable interlocking concrete pavers (PICPs), and also on available street sweeping equipment, are reviewed in some detail. Special drainage cell geometries, called cupules, in specific PICPs were tested under moving regenerative-air pick-up heads in a laboratory rig, and early results have been discussed in a previous paper. Reported here are follow-up field tests on three different parking lot pavements at one installation of rapidly cleaned out PICPs (RCPP) using a wide range of readily available street cleaning equipment. Rapid cleanout of the special purpose cupules at various sweeper speeds is measured and reported for a regenerative air sweeper, two types of mechanical sweepers, and a portable blower with two pick-up head directions of travel and for different filter media. A cost comparison of sweeper performance is presented. Preliminary results of these initial RCPP field tests evidently conflict with recommendations by authorities. Results are, however, considered to be initial, because of insignificant diminution in surface infiltration rates caused by clogging. However, according to the present study, routine RCPP management should ensure that rapid cleanouts similar to those observed here will continue to be experienced over extended time, and RCPP left uncleaned for a prolonged time will be restored more quickly and easily than is the case with the current generation of PICPs. Inexpensive and easy renewal of filter media could lead to improved pavement and deicing management strategies. Accompanying this paper are two short videos that show our field procedures for pavement installation, cleanout and restoration. An algorithm is provided for estimating minimum cost cleanout of PICPs.
\end{abstract}

\section{Introduction}

Whether planning, designing, constructing or managing a permeable interlocking concrete pavement (PICP) installation, it is morally imperative to provide and sustain surface infiltration capacity over the long term, allowing an adequate volume of stormwater to be captured and treated by the facility. Besides the area of the contributing drainage area, PICP infiltration capacity is dependent upon factors such as drainage cell density and permeability; surface slope; surface ponding; pavement base permeability, drainage and void volume; grading and quantity of surface dust and dirt applied; duration and intensity of applied surface loads (such as traffic); and, above all, upon proper pavement management. Designing and constructing a new system to provide appropriately high infiltration capacities is not problematic, but maintaining infiltration capacity over several decades has proven to be a concern, if not actually challenging. The obvious solution is pavers that are quickly, easily and cheaply restored by a variety of sweeping equipment, and this is the nub of the present paper.
An earlier paper (James and von Langsdorff 2016) described laboratory tests of a new PICP designed to be readily cleaned out. Where clogging of drainage cells in PICPs is dominantly in the upper parts of the filter media, as it is in most cases, infiltration rates in special PICPs may be rapidly restored if the PICP design is dovetailed to the fluid mechanics of the street cleaning equipment. PICPs described in this paper have special purpose cupules, or concave filter recesses in the upper surface of the block; more generally, cupules are recesses in a larger body, as seen in anatomy and archeology; they have one surface which is generally concave, whereas a cup has both an internal concave and an external convex surface. In our application, the cupules are designed to facilitate the rapid removal of filter media and filtrate by routine street cleaning equipment at economical speeds. Below the cupules, the drainage conduits are designed to provide specified maximum or controlled drainage flow rates, as shown in Figures 1 and 2 (and later in Figures 6 and 7 below). Furthermore, the geometry of these cupules also meets the requirements of the Americans with Disability Act (ADA 2010), as well as certain requirements for mass production.

James, William, Harald von Langsdorff and Michael McIntyre. 2018. Permeable Pavers Designed for Rapid Renewal by Considering Sweeper Mechanics: Initial Field Tests. Journal of Water Management Modeling 26:C450. https://doi.org/10.14796/JWMM.C450

(c) CHI 2018. www.chijournal.org ISSN 2292-6062. 


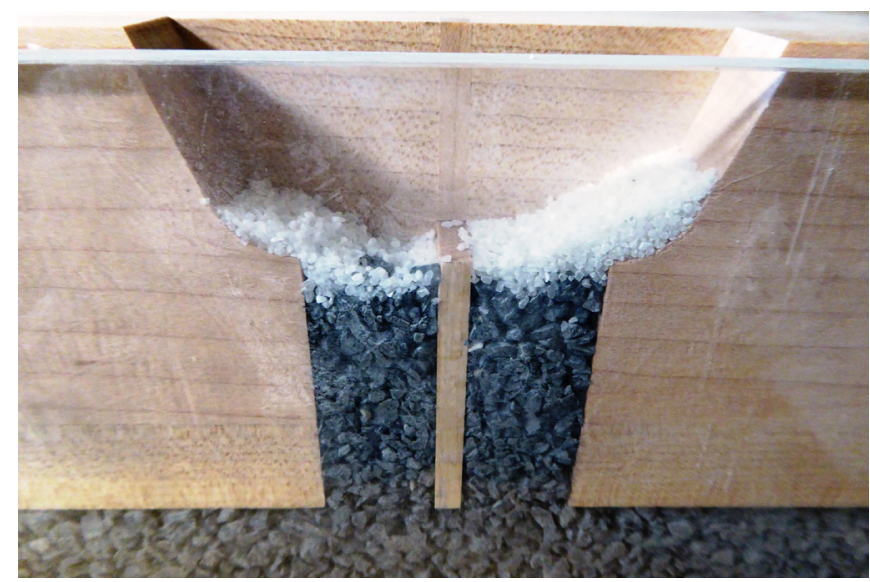

Figure 1 Typical test block enclosed in a plexiglass ampule: remnant of white aggregate in cupule, dark aggregate in conduits and bedding layer; cupule width is $12.5 \mathrm{~mm}$ (test cupules had sharp edges).

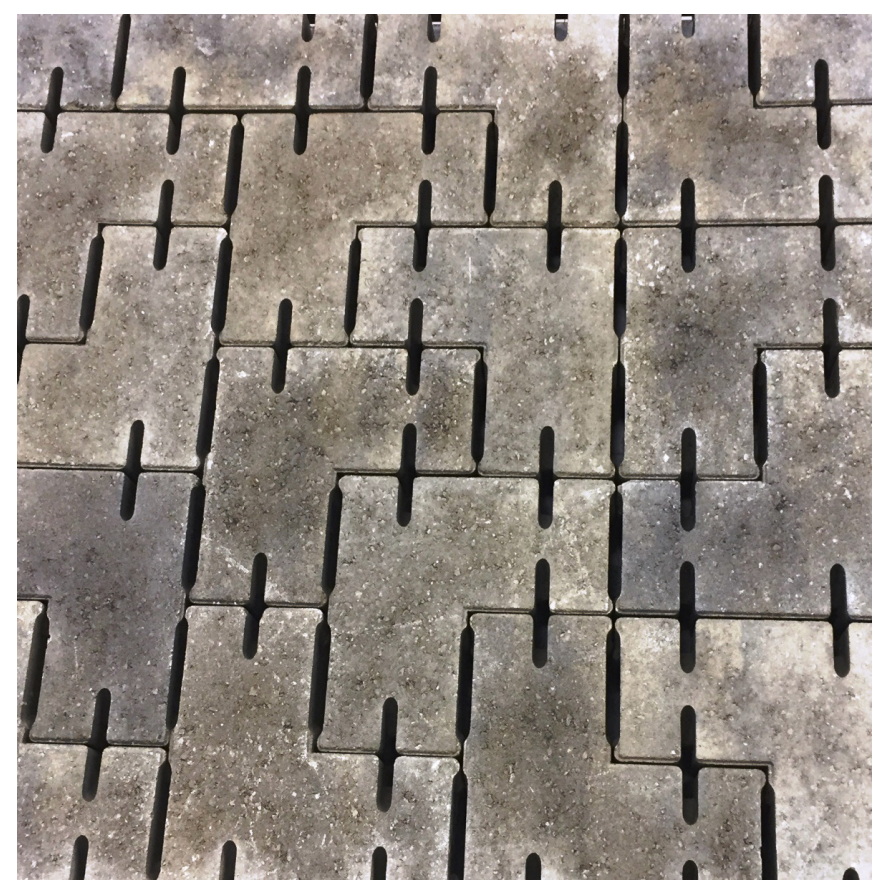

Figure 2 Pavement constructed from two forms of L-shaped PICP blocks with cupules of two different lengths aligned in the direction of sweeper travel; real cupules have rounded edges, cupule width is $12.5 \mathrm{~mm}$, block joints are typically $2 \mathrm{~mm}$ wide.

Our earlier paper (James and von Langsdorff 2016) demonstrated that infiltration rates in these new PICPs, denoted $\mathrm{RCPP}$, may be rapidly restored if their design is dovetailed to the aerodynamics of the regenerative air street sweeper (RASS) at the pavement surface. In that earlier paper, we describe experiments carried out in Guelph, in Southern Ontario, using a rig designed to reveal the air flow at the pavement surface of a simulated RASS pickup head moving horizontally over test blocks having geometry similar to the RCPPs. Cupules in the test blocks were filled with dry, non-cohesive and uncontaminated filter media. In later studies the issue of cohesiveness in the filter aggregate in the cupules will be taken up. The earlier paper described our experimental rig and demonstrated the cleanout principles, and included CAD files of detailed drawings of the components of the rig and test blocks, and a slow-motion video clip of the cleanout processes (James and von Langsdorff 2016). In the present paper we describe tests on a real PICP pavement constructed in Ayr, Ontario using RASSs and mechanical street sweepers (MSSs) with stiff bristles rotating vertically in the plane of the direction of sweeper travel.

We have not discovered any previous literature covering the design of drainage cells in PICP for rapid cleanout by conventional street sweepers. While Scholz and Grabowiecki (2006) review current trends in research and industry on permeable pavement systems, and recommend future areas of research and development, they do not mention PICP with attributes such as the RCPP presented here.

In their manual Permeable Pavements (Eisenberg et al. 2015) the American Society of Civil Engineers states that permeable pavement will continue infiltrating if the top surfaces are cleaned regularly "with regenerative vacuum sweepers at a recommended minimum of twice per year." Surfaces that are clogged due to lack of regular surface cleaning can be restored by RASSs, which are recommended for regular cleaning, while pure vacuum type units (VSSs) are recommended only for the restoration of severely clogged surfaces that have not been vacuumed regularly. Simple (mechanical) broom sweepers (MSSs) are not recommended since "they do not collect and remove accumulated debris." The Interlocking Concrete Pavement Institute reiterates precisely the same injunctions (ICPI 2006), and so do other authorities. However, neither manual covers RCPPs such as those discussed here, having been published before the advent of our RCPP, so it is not surprising that our results may to some extent contradict their (and derivative) recommendations.

\section{Research Background}

In this section we review previous publications in the research literature that relate to the design and testing of RCPP, especially PICP cleaning. Publications on other forms of porous pavement are reviewed if relevant, but generally we do not review research on porous asphalt or on porous or pervious concrete pavement.

\subsection{PICP Infiltration Processes}

Ferguson (2005, ch. 9) gives a good introduction to open-jointed paving blocks in Porous Pavements, which is part of a series of integrative studies in water management and land development. Detailed descriptions of the physics of interfacial water flow vertically and laterally in the drainage cells, bedding layer, base and sub-base of PICP are hard to find. Brown and Borst $(2013 ; 2015)$ studied the infiltration and clogging processes of PICP, using time domain reflectometers (TDRs) to measure spatial infiltration and 
to assess the clogging dynamics of permeable pavement systems. Paired TDRs were installed at two locations in each permeable pavement type in a 0.4 ha parking lot with three permeable pavement types (including PICP) at a depth of $0.4 \mathrm{~m}$ below the driving surface. Results indicated that clogging progressed from the upgradient edge. They suggest TDRs for maintenance scheduling.

Water percolating through PICP interacts with air, water vapour, dust, and gravel and concrete surfaces in the pores, and the evacuation and replenishment of the displaced air is seldom considered. In dry weather, air and water vapour replaces liquid pore water during percolation, aided by evaporation. Brown and Borst (2015) also studied evaporation at their installation, using a water balance approach. Average cumulative evaporation from the permeable pavement sections for 134 rainfall events in 24 months was $5.2 \%$ of the cumulative rainfall volume, and the range was $2.4 \%-7.6 \%$. Thus evaporation comprises a small part of the total water budget on an annual basis, and we therefore assume that percolation by gravity is the dominant process, with the displaced air escaping by moving upwards against the water. At this scale the interfacial fluid flow is viscous and restrained by surface tension. Both viscosity and surface tension are affected by changes in temperature: as temperature increases both water viscosity and surface tension decrease. Infiltration at low temperature is of concern; we found no published temperature corrections.

\subsection{Measurement of Infiltration}

Vertical and lateral (horizontal) saturated hydraulic conductivity (SHC) of the bedding and base layers is the central attribute of PICP, and accurate estimation of SHC is clearly paramount. An explanation of the physics is given by Clyne et al. (2001). Reviewing theories, they concluded that the Minnesota Department of Transportation permeameter can reliably estimate the base SHC if the base layer is $\geq 150 \mathrm{~mm}$ thick. When the base layer is thinner, permeameter readings are restricted to early infiltration times (MPCA 2017). In our test pavements the RCPP bedding layer is $<150 \mathrm{~mm}$ thick, so we deduced from this advice that infiltration measurements using ASTM standard C1781 (ASTM 2015) should use low total volumes of water, and we used volumes weighing $8.5 \mathrm{~kg}$ or $17 \mathrm{~kg}$. Note that in our field studies SHC of the base layer was an order of magnitude lower than that of the bedding layer.

Sampling infiltration is complex by virtue of its spatial variability, as well as the varying antecedent moisture. Brown and Borst (2014) evaluated surface infiltration testing procedures in permeable pavement systems using ASTM C1701 (ASTM 2015), focusing on how testing sites should be selected and recommending that surface infiltration testing should strategically select fixed testing locations based on expected clogging patterns. In our present test pavement, no clearly defined points of runon existed, and no defined sources of clogging were expected, so although we spaced some of our tests randomly, we also repeated measurements at approximately the same places within the three regions of the new pavement surface, simply because spatial variations were noted by other workers.

Subsequently, in 2015 the American Society for Testing and Materials (ASTM) produced a standard, simple infiltration estimation procedure for PICP: C1781 Standard Test Method for Surface Infiltration Rate of Permeable Unit Pavement Systems (ASTM 2015). Because of its single-handed ease, low cost and speed, C1781 was adopted in recent PICP studies and is used in this study, notwithstanding Clyne et al. (2001).

\subsection{Clogging in PICP}

All literature reviewed confirms that PICPs initially have very high infiltration capacities, normally ten times design storm specifications, but clog with age and use. Literature also confirms that regular cleaning (RASS is frequently mentioned) can restore most of the initial infiltration rate. Maintenance is a key concern. Noteworthy in the papers listed below is the scant or absent attention paid to the suitability, operation and operational condition of the street sweepers employed. Our observations are that the individual sweeper hardware characteristics account for more than half of the variance attributed to the paver-sweeper combination. Thus researchers may ultimately recommended pavement maintenance schedules based on unknown and arbitrary sweeper characteristics, assumed to be representative of the class. We return to this point later, for instance in List $\mathrm{C}$ below.

Table 1 Literature reviewed (papers cited are fully referenced at the end of this paper).

\begin{tabular}{llccc}
\hline \multicolumn{1}{c}{ Date } & \multicolumn{1}{c}{ Lead Author } & PICP? & Sweepers & Notes \\
\hline 2002 & Wilson & Y & 1,2 \\
2002 & UWRC & Y & 2,3 \\
2003 & Tan & N & 4 \\
2003 & Brattebo & Y & \\
2003 & Abbott & Y & \\
2004 & James & Y & & 2,4 \\
2006 & Collins & Y & & \\
2009 & Pezzaniti & Y & & 2 \\
2010 & Chopra & Y & VSS & 2 \\
2011 & Lucke & Y & & \\
2012 & Sansalone & N & VSS & \\
2012 & Vancura & N & RASS, VSS & 1 \\
2013 & TRCA & Y & \\
2015 & Al-Rubaei & Y & \\
\hline Notes & & & \\
1 Recommends maintenance. & & & \\
2 Applies sediment. & & \\
3 Recommends run-on avoidance. & & \\
4 Predicts clogging rate. & &
\end{tabular}

Summarising our review of the above papers, we infer that obvious factors that affect clogging are subsumed into three lists as follows. 


\section{List A}

Beyond the size of the runoff area, factors that affect clogging (1 to 6 ) that have been repeatedly researched and reconfirmed since the very earliest tests are:

1. Quantity of filtrate or particulate matter, formerly called dust and dirt (i.e. mass rate, gradation, chemical nature);

2. Quantity of general waste and organics such as leaves and paper products;

3. Formation of a surface crust of low permeability;

4. Type of street cleaner;

5. Time since last cleaning; and

6. Runon from adjacent areas, especially if concentrated.

\section{List B}

Factors that affect clogging (7 to 17) that, though obvious, are generally left unstated:

7. Application of deicers;

8. Age, material and condition of the pavement;

9. Consolidation of and surface drainage of the pavement itself (e.g. depressions);

10.Subgrade and slope;

11.Pavement and tyre wear caused by traffic (e.g. frequency, speed, weight, tyres);

12.Vegetation sprouting and decaying in the pavement;

13. Biota within the drainage cells;

14. Antecedent rain or lack thereof;

15. Moisture content of the filter media, bedding layer, base and sub-grade;

16. Stormwater flows over the surface; and

17. Other weather (e.g. climate, snow, ice, wind, heat).

\section{List C}

Factors that affect clogging (18 to 25) that, from the above admittedly selective review, we found were ignored in previous studies, and are hypothesized here as novel and potentially noteworthy considerations:

18. Consolidation of the particulate matter in the drainage cells by impressed loads;

19. Quality of the street cleaners;

20. Operational performance of the street cleaners;

21. Operational settings for the street sweeper, including speed over the ground;

22. Grain size distribution of the combined filter media and filtrate,

23. Type and wear of the concrete blocks and filter media;

24. Airflow in the pores of the filter media and bedding; and

25. Vibration of the pavers caused by traffic.

\subsection{Restoring Infiltration in PICP}

Very likely, similar factors also affect the restoration of PICP drainage cell infiltration capacity, for which we now review related literature.

In the 1990s the lead author and his students tested the hypotheses that infiltration capacities decrease with age and certain land uses, and that infiltration capacities may be improved by street sweeping or vacuuming (Thompson and James 1995; James and Verspagen 1997; Kresin et al. 1997; James and Shahin 1998). Of course, the laboratory test blocks were not subjected to wear or the deposition of pollutants over time on the surface and, therefore, performed under optimal conditions. The research also used data collected at several Uni-Ecostone PICP installations, and showed that there is little difficulty in designing and constructing a system to provide appropriately high infiltration capacities; however, sustaining infiltration capacities over many decades requires vigilance.

The effectiveness of methods used to restore the infiltration capacity of permeable pavers was reported in 2003 by James and Gerrits (2003). Street sweeping and vacuuming the surface to maintain the infiltration capacities of permeable pavers was investigated using an $8 \mathrm{y}$ old installation of two different types of permeable pavements in a parking lot at the University of Guelph. No maintenance procedures had been used over the 8 y period, other than snow removal and street sweeping with rotating brushes 1 time/y in spring. Infiltration rates were tested before and after material was systematically and increasingly extracted from the EDCs (external drainage cells) and subjected to a particle size and constituent analysis. Extracted material was also tested for a number of different organic and chemical constituents such as heavy metals, nutrients and organic matter. Results indicated that the infiltration capacity decreased with increasing average daily traffic counts, and as the amount of organic matter (other than vegetation) and fine matter in the EDC material increased. Furthermore, the tests indicated that the infiltration capacity could be significantly improved by removing $10 \mathrm{~mm}$ to $20 \mathrm{~mm}$ (0.4 in. to $0.8 \mathrm{in}$.) of EDC material, a removal depth that might be achieved using certain equipment.

Some decades later, Drake and Bradford (2013) assessed the potential for the rehabilitation of surface permeability using RASSs and VSSs. A RASS was tested on two parking lots with wellused PICP while a VSS was tested on a third parking lot with PICP. Spatially variable partial rehabilitation was observed that was attributed to "micro-conditions throughout the pavement having a confounding influence on the overall effectiveness of maintenance." They did not elaborate on the micro-conditions, but recommended regular cleaning intervals and instructional guidelines for pavement owners and equipment operators. From James and Gerrits (2003) we suggest that the suggested micro-conditions were conceivably wholly or partly caused by the uneven spatial distribution of fine particulate matter (PM) accumulating in the drainage cells. 
In fact, the Minnesota Pollution Control Agency's Minnesota Stormwater Manual website (MPCA 2017) recommends certain key actions to help ensure the long term performance of permeable pavement during its operational life. Surface clogging caused by organic matter and sediment can be reduced by periodic vacuuming $\geq 2$ times/y, typically at the end of winter (April in Ontario) and after autumnal leaf fall (November in Ontario); at least one pass should occur at the end of winter. RASSs are again the suggested means of regular surface cleaning, while, for neglected surfaces (those with no surface cleaning over several years) true VSSs rather than RASSs or MSSs should be used. Aggregate removed from the joints should be replaced with similar material. Evidently the Minnesota Stormwater Manual reiterates advice in the ASCE manual (Eisenberg et al. 2015) and may also be contradicted by our findings for RCPPs.

\section{Types of Street Sweepers}

For many activities and users (e.g. industrial, municipal, agricultural, civil engineering, highway maintenance, land development, construction, institutions, landscapers and homeowners), manufacturers offer suites of machines and tools for picking up, transporting, storing and disposing of debris of all kinds. Street sweepers are a case in point.

Wikipedia gives a brief historical background description of street sweepers and their development (Wikipedia 2018). In England, circa 1843, Joseph Whitworth invented a mechanical street sweeper; the first street sweeping machine was patented in the United States in 1849 and the first self-propelled street sweeper truck in 1895. When increased concern for water quality emerged in the 1970s, street sweeper goals changed, as reflected in street sweeper patents in the 1990s (see Table 2 below).

\subsection{Categories}

By considering only the general mechanics of the machines, Eisenberg et al. (2015) identified three types of pavement (street) cleaning equipment: mechanical street sweepers (MSSs), RASSs and VSSs as described below:

1. MSSs are currently the most common street sweeper for use on impervious pavements. Brushes move litter and sediment to the machine's center, and another brush then lifts them onto a conveyor belt and thence to the machine's hopper. Brush bristles can penetrate some types of permeable pavements, depending on their elevation settings, but may not collect fine dust particles. Brushes wear out and must be replaced. In our tests we used the personal $24 \mathrm{in} .(63.5 \mathrm{~cm})$ Power Sweeper by Iron Fist and the Tennant S30, whose bristles had worn to a length of $55 \mathrm{~mm}$, probably $33 \%$ of their original length.

2. RASSs are the second most common street cleaner. They have a rotary sweeper that loosens dirt and sediment, which can then be vacuumed into the hopper. Fast moving air is recirculated within a pick-up head mounted across the entire truck width, which creates an adjustable vacuum directly over the pavement surface. In our tests we used a Johnston RT655 on which a side skirt was damaged.

3. VSSs are typically the most expensive type of street sweeper, and are often equipped for multiple functions. VSSs are equipped with rotary brushes for loosening surface dirt prior to vacuuming. A strong vacuum is applied to an intake nozzle, positioned on the pavement, that lifts particles from the surface and within the pavement. The intake is $\sim 1 \mathrm{~m}$ wide and applies a vacuum force at least twice that of a RASS; thus it is claimed that VSSs can be effectively used for restoring clogged PICP. However, the narrower width of suction increases cleaning time. In our current experiments we have yet to test a VSS. Vacuuming is most effective when the sediment within PICP and other permeable pavement surfaces is as dry as possible.

It seems that ASCE were considering Industrial and Highway classes of street sweepers. In any case, their compartmentalisation of street sweeper types is necessarily simplistic, as each type may, or is likely to, contain elements of the others: for example, in MSSs: roller brushes are arranged orthogonally or obliquely to the RASS travel direction, forward or aft of the pick-up head; hot or cold water jets; air jets; and vacuum. Thus sweeping equipment may be better categorised by capacity (or purpose), as it is by no means clear that more expensive equipment will do a better job of cleaning in a given PICP situation, and generally the smaller the capacity of the equipment, the lower the cost. For instance, power blowers are not mentioned at all in the PICP manuals and literature. We tested an inexpensive lightweight portable power blower with a significant scouring air velocity and found it highly effective (but, overall, operationally tedious) in scouring to greater depths than all other methods in our RCPPs. High speed blowers mounted on driven carriages are yet to be tested.

Categorisation by manufacturer is not attempted here, since there are too many; the website Environmental-expert.com alone lists 82 street sweeper manufacturing companies (see link listed in the references, Environmental Expert 2018). Manufacturers of equipment commonly seen in Ontario include: Elgin, Johnston, Schwarze, Tennant, and Tymco.

Classification by capacity or purpose may be more sensible; for example: freeway and highway cleaners; large parking lot cleaners; small lot cleaners; sidewalk cleaners; or private property cleaners. We decided to test a small number but a wide variety of items of this equipment, since the effort will likely help equipment operators and pavement owners select a single piece or (better) combination of cleaning equipment (for tandem cleaning). 
Once cleaned out the cupules may be fully or partially refilled. Refilling openings or joints is (at the time of writing, 2016) done by manual or mechanical broom sweeping of selected aggregate into openings and joints, as shown in the videos attached to this paper.

\subsection{Effectiveness of Cleaning Equipment}

No purpose-designed equipment for cleaning PICP, let alone RCPP, has been discovered by the authors in extant literature. However, work has been done designing and building experimental cleaning equipment for pervious pavements, and some prototype equipment is currently under development.

Infiltration capacity and function of $1 y$ to $5 y$ old pervious road pavements at 15 sites located near the Swedish west coast were studied by Hogland and Wahlman (1988). They plotted damage on the asphalt surfaces, measured infiltration capacity, and drill-sampled the asphalt and materials at different levels in the pavement. Results showed that the infiltration capacity of the asphalt decreased, even during normal traffic loads, if the surface is not cleaned regularly. A promising method for cleaning clogged surfaces was tested in situ and in the laboratory, and it was concluded that pervious pavement is suitable for use on surfaces with low traffic intensity )such as parking lots, industrial areas, pedestrian roads and bicycle roads) when no overland flow can occur from adjacent surfaces; appropriate deicing methods are used; and the pavement surface is cleaned regularly to maintain infiltration. While the equipment may not suit RCPP, the principles underlying its development are interesting.

By testing and modifying existing equipment, Flyhammar (1991), also in Sweden, developed a special purpose cleaning machine, again for pervious asphalt. High pressure water jets with and without suction were used to rinse and open up the friction courses. In Norway and Sweden, studded tires were in use and they increased clogging. To clean clogged surfaces with low traffic intensity they found that a water jet at 100 bar (10 MPa) water pressure will probably suffice. Some pavements may require cleaning 1 time/y to 2 times/y while others may not need to be cleaned at all. Major clogging events must be taken care of quickly. An absolute minimum cleaning frequency is 1 time/y while a few cleanings a year is better. Interesting as the principles of the device may be, in our application air might be more effective than water, being less likely to drive fine PM down into the bedding layers.

The ability of several different sweeping technologies to pick up accumulated sediment of various sizes was evaluated by Sutherland and Jelen (1997). They suggested that reductions of up to $80 \%$ in annual TSS and associated pollutant washoffs might be achieved by using bimonthly to weekly sweepings. It was clear that sweeping technology can affect sweeping results and achieve meaningful runoff quality benefits. In 1996-05 the Port of Seattle conducted an evaluation of selected stormwater treatment best management practices (BMPs) for the port's marine terminals (Sutherland et al. 1998). High efficiency weekly pavement sweeping with normal sediment-trapping stormwater inlets cleaned annually had a life cycle cost of approximately one tenth that of wet vaults, mainly because heavy covers were necessary for the latter.

Tobin and Brinkmann (2002) tested the effectiveness of two different sweeper types in removing sediments, heavy metals and organic constituents from a paved surface. Both a MSS and a RASS were tested on an asphalt roadway. The results indicated that while rotary brush sweepers were more effective in removing total sediment loads from roads, each sweeper was effective in removing particular chemicals from streets, and neither sweeper proved better in all categories. The effectiveness of street sweeping, washing and dust suppressants as urban PM control methods was reviewed by Amato et al. (2010), who separated street sweeper types into the usual three categories: MSS, VSS and RASS units. Potential measures to reduce emissions of PM from abrasion and resuspension processes were studied, but the two driving forces for municipalities to keep streets clean were found to be aesthetics and sanitation. (Today, efforts are likely to be directed towards reduction of TSS and other pollutants when draining to combined and storm sewer systems.)

In their tests of street sweeping Sutherland and Jelen (1996) found that tandem street sweeping (i.e. MSS followed by VSS) was much more effective than had been previously concluded by the Nationwide Urban Runoff Program (NURP).

Vancura et al. (2012) observed that pervious concrete void maintenance depends on what machines owners have available and that they choose to use. They compared the abilities of three common municipal utility vehicles to unclog in-service pervious concrete pavements: a vacuum truck with a flexible $200 \mathrm{~mm}$ hose; a VSS; and a RASS. Using optical microscopy, they found that clogging materials rarely migrate into voids deeper than $12.7 \mathrm{~mm}$ from the surface. All three machines were able to remove clogging materials that were located within $3.2 \mathrm{~mm}$ of the surface; but clogging materials located deeper than $3.2 \mathrm{~mm}$ remained within the voids, likely disturbed by the suction and forced air of the maintenance vehicles.

Researchers using VSSs and RASSs (or indeed MSSs) have typically not reported the mechanical details of the equipment used, possibly because the details may have been regarded as proprietary knowledge. For the RASS used in this study we published details of the pick-up head in our previous paper (James and von Langsdorff 2016). Many details can be gleaned from information held by the U.S. Patent Office. Links given in Table 2, with the filing year and assignee, were found by a simple Google search for street sweeper pick-up head patents. Opening the links and zooming into the technical drawings, one discerns the evolution of the technology as shown simplistically in Table 2. From these ideas, modifications for a device for restoring RCPP can be devised (the term of a patent is generally $20 \mathrm{y}$, so most patents listed in the tables have already expired, or soon will). 
Table 2 Pick-up patents: filing date, assignee, effect of patent and link.

\begin{tabular}{|c|c|c|}
\hline Filing Year & Assignee & Effect and URL \\
\hline 1966 & B.W. Young & $\begin{array}{l}\text { Suction chamber combined with blower } \\
\text { https://www.google.com/patents/US3512206 }\end{array}$ \\
\hline 1967 & $\begin{array}{l}\text { Wayne } \\
\text { Manufacturing }\end{array}$ & $\begin{array}{l}\text { Vacuum with brushes } \\
\qquad \text { https://www.google.com/patents/US3436788 }\end{array}$ \\
\hline 1977 & FMC Corp & $\begin{array}{l}\text { Has two vacuum chambers } \\
\qquad \text { https://www.google.com/patents/US4109341 }\end{array}$ \\
\hline 1981 & Jimmy Tate & $\begin{array}{l}\text { Has constriction with venturi effect } \\
\qquad \text { https://www.google.com/patents/US4359801 }\end{array}$ \\
\hline 1987 & Tymco & $\begin{array}{l}\text { Mounts a pickup head below a light pickup truck } \\
\text { https://www.google.com/patents/US4773121 }\end{array}$ \\
\hline 1984 & Tymco & $\begin{array}{l}\text { High speed elongated blast orifice, chambers with decreasing volume } \\
\text { https://www.google.com/patents/US4660248 }\end{array}$ \\
\hline 1995a & Tymco & $\begin{array}{l}\text { Pickup head includes transverse roller brush forward of vacuum } \\
\text { https://www.google.com/patents/US5542148 }\end{array}$ \\
\hline $1995 b$ & Tymco & $\begin{array}{l}\text { Same as last, but brush is rear of vacuum } \\
\qquad \text { https://www.google.com/patents/US5560065 }\end{array}$ \\
\hline 1996 & Elgin & $\begin{array}{l}\text { Pickup head with lower noise level } \\
\text { https://www.google.com/patents/US5839157 }\end{array}$ \\
\hline 1997 & Elgin & $\begin{array}{l}\text { Speed increased, similar to the pick-up head used in our study } \\
\text { https://www.google.com/patents/US5852847 }\end{array}$ \\
\hline
\end{tabular}

\section{Pavement Surface Cleanout Processes}

From the above literature, and with imagination, we propose the following (non-exhaustive) list of processes that may inform the RCPP cupule cleanout function (some are repeated from the lists of clogging processes above):

- geometry of the drainage cells;

- alignment of the cupules;

- filter media in the cell (size, gradation);

- nature and gradation of clogging filtrate in the filter media;

- movement of air through the cell from below;

type of cleaning equipment;

speed of the cleaning equipment;

alignment of the cleaning machine;

operational efficiency of the cleaning equipment;

shape, length and rotational speed of brushes, if any;

water velocity at the cell, if any;

air jet velocities at the cell, if any;

vacuum velocities at the cell, if any;

- fluid mechanics (e.g. turbulence) of airflow at and in the cell;

- lift, entrainment and removal of the largest filtrate particles;

- vibration of the pavers caused by the cleaning equipment;

freezing temperatures;

- consolidation and compaction of the particulate matter in the drainage cells;

- wear caused by traffic factors (e.g. frequency, speed, weight, tyres);
- supply of general waste and organics, such as leaves, forming a crust;

- vegetation sprouting in the pavement;

- biota within the drainage cells;

type and quality of the street cleaners and their operational performance;

- operational settings for the street sweeper, including speed over the ground;

time since last cleaning;

antecedent rain or lack thereof;

moisture content of the filter media, bedding layer, base and sub-grade;

local run-on from adjacent areas;

other weather conditions (e.g. snow, ice, wind);

deicing chemicals;

age, material and condition of the pavement;

consolidation of and surface consistency of the pavement itself (e.g. depressions); and

slope.

\subsection{Freezing, Groundwater and Modeling}

Bäckström (1999) comprehensively studied porous pavement in a cold climate during freezing, thawing and snowmelt conditions in order to evaluate whether porous pavement is suitable for stormwater management in cold regions. A full scale porous pavement construction was built in 1993-1994 in a residential area on the outskirts of Luleå, Northern Sweden. In situ measurements of ground temperature, frost heave, groundwater levels and runoff were taken. Draining of the porous asphalt at different ambient air temperatures in the range $-10^{\circ} \mathrm{C}$ to $+20^{\circ} \mathrm{C}$ was also investigated in their laboratory. They found that porous pavements potentially reduce meltwater runoff, avoid excessive water on the road surface during snowmelt, and recharge groundwater. Porous pavement was more resistant to freezing and frost heave than comparable impermeable pavement. Thawing porous pavement was a rapid process, explained by meltwater infiltration and increased air temperature during the beginning of the snowmelt period.

Minimizing salt or sand use for deicing and traction in the winter and keeping landscaped areas well maintained and preventing soil from being washed onto PICP pavement helps increase its life (Minnesota Pollution Control Agency's Minnesota Stormwater Manual, MPCA 2017). Less salt is required than for impermeable pavement. Maintenance agreements should avoid conventional parking lot maintenance tasks such as sanding, re-sealing, re-surfacing and power-washing. Proper winter maintenance is critical (Eisenberg et al. 2015). The following minimum practices are recommended: prohibit sand application whenever possible and post No Sanding! signs; prohibit stockpiling and storage of snow plowed from other areas; and if sand is applied then it must be removed as soon as possible with VSS.

Groundwater contamination is a serious concern for PICP, especially where roadway deicing includes the use of salt, which may then be detected in local groundwater and aquifers; but this 
topic is large and tangential to the present paper. A comprehensive and readable treatment is given by Ferguson (1994), while Pitt and Lantrip (2000) report on infiltration through disturbed urban soils, and Pitt et al. (2003) describe infiltration through compacted urban soils and its effects on biofiltration design.

Several models have been developed for the design of low impact developments (LIDs) that include PICP (Myllyoja et al. 2001; Sutherland et al. 2002; Rivard et al. 2004; ICPI 2009; Rossman 2010; Zhang et al. 2010; Pitt et al. 2011; CHI 2018). Readers are reminded to check whether the models being considered include coding for processes related to the restoration of infiltration capacities. The LID routines in SWMM (CHI 2018) will be informed by the measurements reported in this present work.

\section{Tests on New RCPPs}

New RCPP pavers (James and von Langsdorff 2016) that were designed to meet the American Disability Act (ADA 2010) were installed in a parking lot at the Unilock Plant in Ayr, Ontario on 2016-11-26-27, and the construction can be seen in a $2 \mathrm{~min}$ video attached to this paper (https://youtu.be/gx39ejkvlcg). In a single installation, three different pavements were built, each having different cupule filter media:

1. Cupules arranged in the direction of travel, white aggregate (test 2 in Figure 3 below);

2. Cupules arranged in the direction of travel, HPB (a common class of Ontario aggregate) in conduits (drainage cells below the cupules), with paver jointing sand (PJS) in the cupules (test 1 in Figure 3 below); and

3. Cupules arranged transverse to the direction of travel, HPB in the cupules (test 3 in Figure 3 below).

Tests of transverse cupules were included as some permeable pavement owners would not want the cupules cleaned out when performing frequent sweeping (daily or weekly, typically intended not to regenerate infiltration but simply to remove trash and debris) and when having to refill aggregate could be problematic.

At the outset, it must be noted that our tests and conclusions are for single passes of the sweeping equipment, because we are here concerned about effective cleaning, and cleaning costs are obviously related to cleaning time (duration) and thus number of passes.

Field cleanout tests were conducted 2016-11-23 09:00 $\mathrm{h}-11: 00 \mathrm{~h}$ under overcast conditions, air temperature $-5^{\circ} \mathrm{C}$, overnight low $-10^{\circ} \mathrm{C}$. Conditions were distinctly suboptimal as tests were conducted on a pavement that was essentially at a temperature noticeably below freezing; infiltration and water scour tests were impossible. The likely effect of subzero paver temperatures would have been for moist frozen aggregate to bind to the pavers, though this was not noticed. However, the PJS, supposedly dry in sealed plastic bags, had frozen solid, with the result that it was difficult to break up, spread and sweep into the cupules. In the end, a heavy forklift truck was driven over frozen clumps of sand, to break them up, effectively compressing them into the cupules; not a typical pavement situation, but still of interest (one could use this method for accelerated aging tests). For these reasons the tests did not produce systematic scour of filtrate in the cupules.

As shown in our second accompanying video (https://youtu.be/pCxzxF_5AHo) two street cleaners were operated by dedicated, experienced operators at two speeds: first $\sim 7 \mathrm{~km} / \mathrm{h}$, and then a second pass followed at $\sim 22.5 \mathrm{~km} / \mathrm{h}$. In neither machine were the controls optimized. The machines were:

1. RASS: Johnston RT655, full vacuum but no water. The blast jet and vacuum air speeds were adjustable, but not tested over their ranges. Vacuum was maximised. Carefully examining the underside of the pick-up head we found that one of the several rubber skirts was missing. It should be noted that skirts wear easily and are readily damaged and seldom make a coherent airtight seal with the pavement because of rugosity and the unevenness of worn pavement. In most research the integrity of the seal is not reported, and it is a possible source of discrepancy. (http://www.johnstonnorthamerica.com/products/ truck-mounted/rt655/); and

2. MSS: Tennant SweepMaxPlus S30, with worn (55 $\mathrm{mm}$ ) brushes, set to their lowest elevation (http:// www.tennantco.com/am-en/equipment/sweepers-rider/mid-sized-rider-sweeper/s30).

The maximum surface curvature (for drainage) of our test pavement was estimated, by straight edge, to be $\sim 10 \mathrm{~mm}$ downwards over $2 \mathrm{~m}$, which may not suit RASS. Cupules were variously filled with accumulated sediments to the top surface of the PICP. Scour was measured by estimating the depth of sediment removed (measuring/estimating vertically from the top surface of the PICP). In the end, both machines produced comparable results, $15 \mathrm{~mm}$ scoured at the higher speed and $\sim 20 \mathrm{~mm}$ scoured at the lower speed. Despite the conditions, this was better scour than we had seen in any field tests on other PICP. Results were probably influenced by the fact that the cupules in both longitudinal pavements were oriented in the direction of travel of the sweeping equipment. The pavement segment with cupules arranged transversely showed no scour for both machines, a result we had hoped for-we were never required to recharge those cupules. The tests proved that both MSSs and RASSs are effective at rapidly cleaning cupules aligned longitudinally, to the extent suggested by all authorities, where pavements are maintained by sweeping twice a year (at the beginning and end of winter). For deeper scour and faster speeds some optimization techniques are recommended (e.g. use lighter, round grain sand in cupules; adjust main brush elevation in the transverse brush in order to reach the invert of the cupule; adjust the blast jet air velocity; install the pavement as flat as possible, to ensure that the cleaning head fits flush with the surface). Tandem cleaning is recommended in the literature. 
Field cleanout tests were again carried out on 2106-11-28 13:30 h-15:00 h, under overcast conditions, air temperature $8^{\circ} \mathrm{C}$, overnight low $2^{\circ} \mathrm{C}$. Conditions were cool but reasonably dry, while the pavement aggregate was damp. Tests were conducted using two inexpensive but commonly available devices: a personal gasoline powered mechanical sweeper (like a homeowner's snow blower) and a lightweight portable gasoline powered (leaf) blower. Infiltration tests were not carried out on the same date. Tests over the cupules covered with PJS showed less scour than those covered with white aggregate or HPB, so PJS was not used to refill the cupules; coloured aggregate and HPB were used for refilling instead. The cupules were left filled for the winter 20162017, after which further tests are envisaged (in the first warm weather, likely April 2017).

The two devices were operated at walking speed, the roller brush at $\sim 2 \mathrm{~km} / \mathrm{h}$ and the leaf blower at $\sim 60 \mathrm{~m} / \mathrm{h}$. Both had a coverage width of about $0.7 \mathrm{~m}$. The devices were:

1. A 196 cc 24 in. power sweeper: Power Fist, brand new (http://www.princessauto.com/en/detail/24-inpower-sweeper/A-p8617409e ); and

2. A $24.5 \mathrm{cc}$ blower: Makita MM4 model BHX2500CA, brand new, $145 \mathrm{mph}(232 \mathrm{~km} / \mathrm{h})$ maximum air speed (https://www.makitatools.com/products/details/ BHX2500CA).

The roller brush produced $\sim 25 \mathrm{~mm}$ scour, if anything slightly deeper than the previous equipment, and, again, did not scour the transverse cupules. On the other hand, the blower produced exceptional results, about $75 \mathrm{~mm}$ scour, tending to throw the aggregate back up at the operator. HPB was, if anything, even more effectively scoured than the white aggregate, and transverse and longitudinal cupules were equally scoured. For these tests, which essentially examine effectiveness of the physical geometry of these concrete pavers in place for a year, blowers are more than adequate for complete cupule cleanout, though progress through an entire parking lot will obviously be slow; a simple cost analysis is given below. Again, this was a better scour than we had seen at any field tests on PICP. Figures 5 to 7 below show the cupules filled, empty and partially emptied. Results supported the orientation of cupules in the direction of travel of the sweeping equipment. As suggested by almost all authorities, namely that PICP be maintained by sweeping 2 times/y (at the beginning and end of winter), we intend to test again as soon as the weather warms up in early 2017.

Our results may contradict the ASCE and ICPI manuals and others that recommend that RASSs are effectively the best at cleaning PICP. These earlier researchers examined different conditions, and did not embrace RCPP. We have not yet tested VSSs. Again, we remind readers that standard manuals ignore blowers.

\subsection{Infiltration Observations}

Using ASTM standard C1781 (ASTM 2015) we measured mean infiltration (of three tests) in the original Eco-Optiloc pavement, before it was removed in order to install the new test pavements, as $5080 \mathrm{~mm} / \mathrm{h}$ (200 in./h).
Before the new RCPP was installed we measured infiltration into the bedding layer as $104140 \mathrm{~mm} / \mathrm{h}$ (4100 in./h), and in the Granular A sub base as $865 \mathrm{~mm} / \mathrm{h}$ (34 in./h). One day after the new RCPP was installed we measured infiltration rates of $3050 \mathrm{~mm} / \mathrm{h}$ to $11700 \mathrm{~mm} / \mathrm{h}$ (120 in./h to $460 \mathrm{in}$./h) in the three different segments shown in Figure 3. Infiltration into the base was considered to be relatively unimportant.

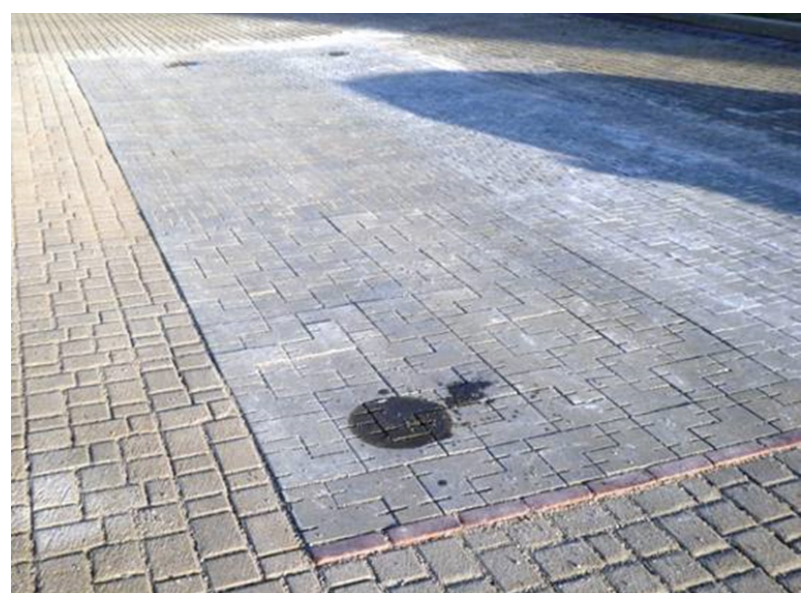

Figure 3 Photo facing NE; test 1 (top left): $6600 \mathrm{~mm} / \mathrm{h}, 260$ in./h; test 2 (top right): $2970 \mathrm{~mm} / \mathrm{h}, 117 \mathrm{in} . / \mathrm{h}$; test 3 (centre foreground): $11550 \mathrm{~mm} / \mathrm{h}, 455 \mathrm{in} . / \mathrm{h}$.

Infiltration tests were also carried out just before the onset of winter, on 2016-12-02, as follows: conditions were overcast, light rain, $2{ }^{\circ} \mathrm{C}$, with overnight freezing. Three measurements were taken in the locations shown in Figures 4 and 5 . For the rings, inside diameter $D=298 \mathrm{~mm}$ and mass of water $M=17 \mathrm{~kg}$ for both buckets together. The formula for infiltration rate $I$ (in $\mathrm{mm} / \mathrm{h}$ ) is:

$$
\begin{aligned}
I= & K \cdot M /\left(D^{2} \cdot t\right) \\
& =4583666000 \times 17 /\left(298^{2} t\right) \\
& =877464 / t
\end{aligned}
$$

where $t$ is in seconds and $K$ is a conversion factor in $\mathrm{mm}^{3} / \mathrm{kg}$.

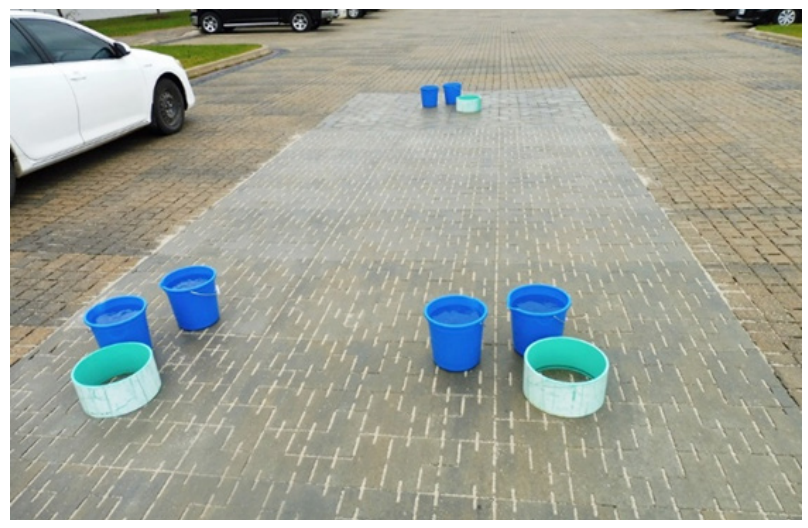

Figure 4 Test pavement viewed towards SW; test 1 (near right): $t=394 \mathrm{~s}, I=2230 \mathrm{~mm} / \mathrm{h}(88 \mathrm{in} . / \mathrm{h})$, white aggregate; test 2 (near left): $t=300 \mathrm{secs}, I=2925 \mathrm{~mm} / \mathrm{h}$ (115 in./h), white aggregate; test 3 (far centre): $t=78 \mathrm{~s}, I$ $=11250 \mathrm{~mm} / \mathrm{h}$ (440 in./h), HPB. 


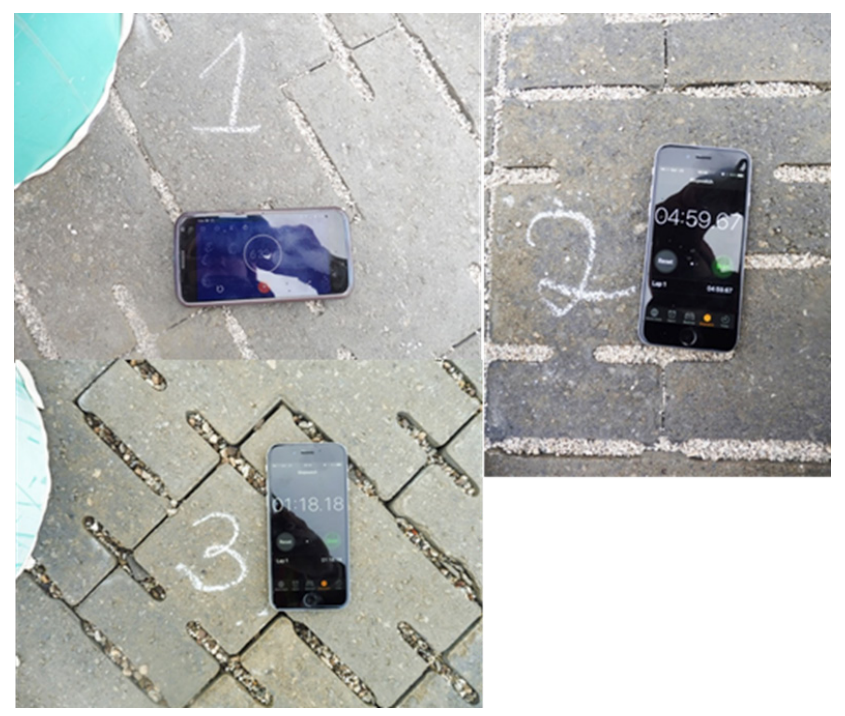

Figure 5 Cupule filter media for each of the three tests.

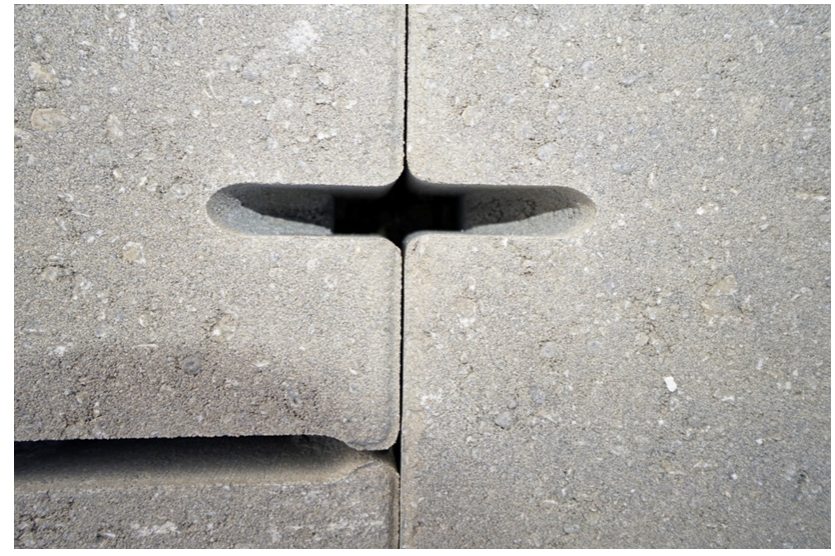

Figure 6 RCPP, clean cupules.

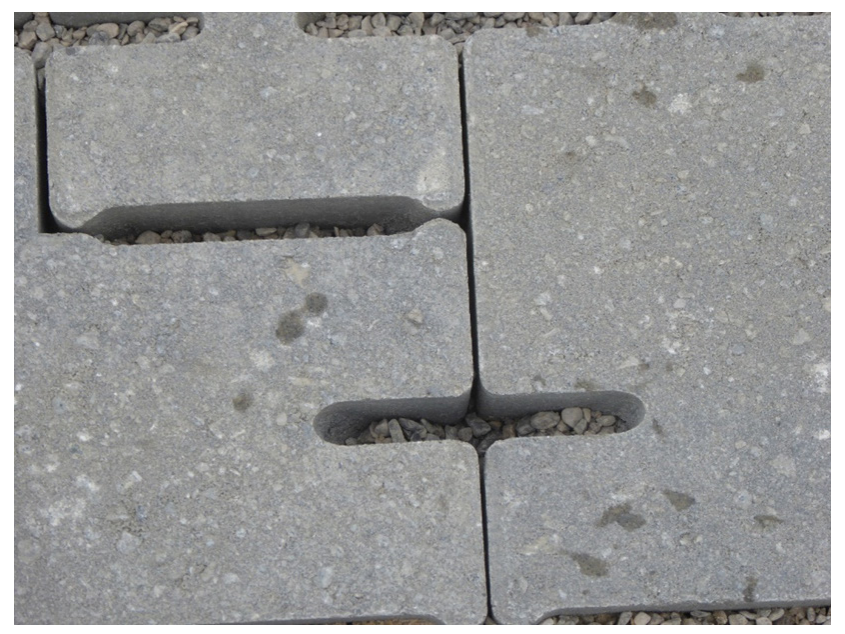

Figure 7 New RCPP, two sizes of cupules, after partial cleanout, HPB grit.

\section{Discussion and Conclusions}

This paper describes field observations of three different RCPP pavements. All had an identical RCPP block, in a single installation, and all were cleaned using four widely differing street cleaning devices, ranging in capital cost over more than three orders of magnitude, from $\sim \$ 350 \mathrm{~K}$ to $\sim \$ 0.15 \mathrm{~K}$ (CAD in 2016). All pavements were, at the least, satisfactorily cleaned by all devices.

One major finding ostensibly contradicts prevailing wisdom, in that expensive truck-mounted RASS machines, though quick, were found not necessarily better than MSS machines, or indeed blowers, at least for our RCPP. On this point we choose to delay making recommendations until we have completed our post-winter pavement sweeping tests in Spring 2017. In the meantime a simplified analysis is offered in the next section.

\subsection{Selecting the Best Sweeper}

Based on the contention that PICP pavement owners are less likely to have their pavements cleaned if the cost is high, some comparative numbers have been run in a simple spreadsheet, based on the above test results (readers are encouraged to enter their own numbers).

The basic algorithm is:

$$
C=c \cdot(W / w) \cdot(L+l) / v
$$

where:

$C=$ incremental cost of cleaning the lot/pavement, CAD,

$c=$ hourly cost of sweeping device, $C A D / h$,

$W=$ width of the lot or pavement, $\mathrm{m}$,

$w$ = width of the cleaning head of the device, $\mathrm{m}$,

$L$ = length of the lot/pavement, $m$,

$I$ = length of one $180^{\circ}$ turning circle, $\mathrm{m}$,

$v$ = speed of sweeper device, $\mathrm{m} / \mathrm{h}$,

and:

$$
c=S / n+O
$$

where:

$$
\begin{aligned}
S= & \text { capital cost of sweeper device, } C A D, \\
n= & \text { designed rental life of the device, } h \text {, and } \\
O= & \text { basic wage (without benefits) of sweeper } \\
& \text { operator, CAD/h. }
\end{aligned}
$$

Clearly, skilled operation and excellent condition of the sweeping device and pavement lead to higher speed and lower incremental cost. Similarly, the cheaper and wider the device, the lower the cleanout cost and consequently the more frequently the pavement or lot is likely to be cleaned (based on cost). By incremental cost we imply the cost of cleaning only, ignoring important costs such as delivery, consumables, disposal and suchlike. The spreadsheet with rough numbers, for a $100 \mathrm{~m} \times$ $100 \mathrm{~m} 1$ ha lot, is given in Figure 8. The final column indicating the cost per $\mathrm{mm}$ scoured in the cupules (over a pavement area of 1 ha 
of course). Wages were taken from the Government of Canada schedule of wages (Government of Canada 2015).

\begin{tabular}{|c|c|c|c|c|c|c|c|c|c|c|}
\hline Incremen & tal cost & t of sweeping & $\mathrm{g}$, tested o & on Ayr R & RCPP test pav & ivement, & , analys & sis 2016.12 & 2.09 & \\
\hline pavement & it size. & width $\mathrm{X}$ lengt & $h(m)$ & & 100 & 100 & & & & \\
\hline Design rer & ntal life & e (h) & & & 4000 & & & & & \\
\hline sweeper & cost & operator/h & cost $/ \mathrm{h}$ & speed & turn length & width & time & inc. cost & depth & cost $/ \mathrm{mm}$ \\
\hline & \$K & $\$$ & $\$$ & $\mathrm{~km} / \mathrm{h}$ & $\mathrm{m}$ & $\mathrm{m}$ & $\mathrm{h}$ & $\$$ & $\mathrm{~mm}$ & $\$$ \\
\hline RASS & 350 & 25 & $\$ 112.50$ & 10 & 10 & 2 & 0.6 & $\$ 61.88$ & 10 & $\$ 6.19$ \\
\hline MSS & 51 & 20 & $\$ 32.75$ & 5 & 5 & 1 & 2.1 & $\$ 68.78$ & 15 & $\$ 4.59$ \\
\hline PMS & 0.9 & 20 & $\$ 20.23$ & 2 & 3 & 0.7 & 7.4 & $\$ 148.80$ & 20 & $\$ 7.44$ \\
\hline PB & 0.15 & 20 & $\$ 20.04$ & 0.06 & 0 & 1 & 166.7 & $\$ 3,339.58$ & 75 & $\$ 44.53$ \\
\hline DRAB & 20 & 20 & $\$ 25.00$ & 5 & 3 & 1.5 & 1.4 & $\$ 34.33$ & 50 & $\$ 0.69$ \\
\hline RASS & Johnst & on RT655 reg & yenerative & air swe & leeper truck & & & & & \\
\hline MSS & Tennar & nt S30 mecha & anical brus & sh swee & eper $(55 \mathrm{~mm}$ & bristles) & & & & \\
\hline PMS & Powerf & fist 24 inch $p$ & ower swe & eper $(n$ & new) & & & & & \\
\hline PB & Makita & MM4 power & $r$ blower B & $\mathrm{BH} 250$ & DOCA (new) & & & & & \\
\hline DRAB & this is & a desired dev & & & & & & & & \\
\hline
\end{tabular}

Figure 8 Rough incremental cost for one 1 ha lot.

In the last line of the table in Figure 8 DRAB is an untested desired combination of numbers that would dovetail with the characteristics of the new RCPP; in other words a sweeper to savour, perhaps a wide, sidewalk or parking lot sized, combined regenerative air-vacuum sweeper (with strong air jets) and transverse roller brush, potentially reducing PICP cleanout cost/mm by an order of magnitude.

Of course, this analysis is directed towards RCPP that is maintained adequately (i.e. cleaned out between once and twice annually) and not towards PICP that was been allowed to seriously clog.

\subsection{Overall RCPP Performance}

It was expected that observed infiltration rates would exceed current design storm requirements; the mean infiltration rates were approximately:

1. Original Optiloc pavers, $200 \mathrm{in} . / \mathrm{h}(5.08 \mathrm{~m} / \mathrm{h})$; new RCPP, from $100 \mathrm{in./h}$ to $500 \mathrm{in.} / \mathrm{h}(2.54 \mathrm{~m} / \mathrm{h}$ to $12.7 \mathrm{~m} / \mathrm{h}$ ) depending on filter media; underlying base, $30 \mathrm{in} . / \mathrm{h}(0.76 \mathrm{~m} / \mathrm{h})$; and

2. Bedding layer, $4000 \mathrm{in} . / \mathrm{h}(101.6 \mathrm{~m} / \mathrm{h})$,

Together, these numbers indicate significant storm hydrograph attenuation; the bedding layer obviously supplies transient storage.

Further tests are intended for the end of winter. Naturally it would be of interest to develop a winter testing methodology, since deicers function at temperatures down to about $-15^{\circ} \mathrm{C}$, and the transport of deicing chemicals into the underlying ground is a serious concern. Winter testing protocols are currently under discussion by the authors.

Finally, inexpensive and easy renewal of filter media in RCPP opens up the encouraging possibility of developing and using media designed for seasonal use: winter media for trapping remnant solid particles of salt and deicers, and summer media for trapping contaminants and particulates generated by summer traffic and local vegetation.

\section{Postscript}

Using PICP reaffirms the age-old axiom: one can only repair a critical condition (in this case local and downstream flooding, groundwater depletion and water pollution) by replacing it with a chronic situation (PICP), which incurs the inevitable price: vigilance (in this case, infiltration maintenance) - a moral that needs to be more widely understood and accepted. As does, a reviewer might add, the moral imperative for PICP manufacturers, owners and researchers to be alert to potential environmental improvements.

\section{Acknowledgments}

This paper is not the final word on comprehensive, long term performance trials, but a description of initial field experiments that set out to test rapid cleanout concepts. Field trials are continuing during 2017. Field tests were conducted on a test RCPP pavement, built by Unilock through Mike Mclntyre, and tested by Bill James and Harald von Langsdorff. Sand and grit were kindly supplied by Mark Latyn of Capital Paving Inc. Jeff MacDonald and Cameron McCrae of Amaco Equipment, Mississauga generously supplied and operated the RASS. The paper was written by Bill James, revised with edits suggested by Harald von Langsdorff and Mike Mclntyre and with helpful suggestions from Bruce Ferguson.

Some manufacturers of common street sweepers are: http://www.johnstonnorthamerica.com/; http://www.elginsweeper.com/; https://www.tymco.com/; http://schwarze.com/; and http://www.tennantco.com/am-en/equipment/all-equipmenta.

\section{References}

Abbott, C. L. and L. Comino-Mateos. 2003 "In-Situ Hydraulic Performance of a Permeable Pavement Sustainable Urban Drainage System." Water and Environment Journal 17 (3): 187-90. https://doi.org/10.1111/j.1747-6593.2003.tb00460.x

ADA (American Disabilities Act). 2010. 2010 ADA Standards for Accessible Design. Washington, DC: United States Department of Justice.

Al-Rubaei, A. M., M. Viklander and G.-T. Blecken. 2015. "Long-Term Hydraulic Performance of Stormwater Infiltration Systems." Urban Water Journal 12 (8): 660-71. https://doi.org/10.1080/1573062X.2014.949796

Amato, F., X. Querol, C. Johansson, C. Nagl and A. Alastuey. 2010. "A Review on the Effectiveness of Street Sweeping, Washing and Dust Suppressants as Urban PM Control Methods." Science of The Total Environment 408 (16): 3070-84. https://doi.org/10.1016/j.scitotenv.2010.04.025

ASTM (American Society for Testing and Materials). 2015. “Designation: C1781/C1781M - 15: Standard Test Method for Surface Infiltration Rate of Permeable Unit Pavement Systems." 
West Conshohocken, PA: American Society for Testing and Materials.

Bäckström, M. 1999. Porous Pavement in a Cold Climate. Luleå: Luleå University of Technology. Department of Environmental Engineering, Licentiate Thesis.

Brattebo, B. O. and D. B. Booth. 2003. "Long-Term Stormwater Quantity and Quality Performance of Permeable Pavement Systems." Water Research 37:4369-76.

Brown, R. and M. Borst. 2013. "Assessment of Clogging Dynamics in Permeable Pavement Systems with Time Domain Reflectometers." Journal of Environmental Engineering 139 (10): 1255-65. https://doi.org/10.1061/(ASCE)EE.1943-7870.0000734

Brown, R. and M. Borst. 2014 “Evaluation of Surface Infiltration Testing Procedures in Permeable Pavement Systems." Journal of Environmental Engineering 140 (3). https://doi.org/10.1061/(ASCE)EE.1943-7870.0000808

Brown, R. A. and Borst, M. 2015. "Quantifying Evaporation in a Permeable Pavement System." Hydrological Processes 29:2100-11. https://doi.org/10.1002/hyp.10359

CHI (Computational Hydraulics International). 2018. PCSWMM. Guelph: $\mathrm{CHI}$. https://www.pcswmm.com/

Chopra, M. B., E. Stuart and M. P. Wanielista. 2010. “Pervious Pavement Systems in Florida - Research Results." In Low Impact Development International Conference 2010: Redefining Water in the City, 193-206. https://doi.org/10.1061/41099(367)18

Clyne, T. R., V. R. Voller and B. Birgisson. 2001. Evaluation of Field Permeameter to Measure Saturated Hydraulic Conductivity of Base/Subgrade Materials: Final Report. St. Paul, MN: Minnesota Department of Transportation.

Collins, K. A., W. F. Hunt and J. M. Hathaway. 2006. "Evaluation of Various Types of Permeable Pavements with Respect to Water Quality Improvement and Flood Control." In Proceedings of the 8th International Conference on Concrete Block Paving, November 6-8, 2006 San Francisco, California USA, 129-39. https://doi.org/10.1061/40927(243)435 https://doi.org/10.1061/41007(331)25

Drake, J. and A. Bradford. 2013. "Assessing the Potential for Rehabilitation of Surface Permeability Using Regenerative Air and Vacuum Sweeping Trucks." Journal of Water Management Modeling R246-16. https://doi.org/10.14796/JWMM.R246-16.

Eisenberg, B., K. C. Lindow and D. R. Smith, eds. 2015. Permeable Pavements. Reston, VA: ASCE (American Society of Civil Engineers).

Environmental Expert. 2018. Street Sweeper Manufacturers Companies. https://www.environmental-expert.com/companies/ page-5/?keyword=street+sweeper+manufacturers

Ferguson, B. K. 1994. Stormwater Infiltration. Boca Raton, FL: CRC Press.

Ferguson, B. K. 2005. Porous Pavements. Boca Raton, FL: CRC Press.

Flyhammar, P. 1991. Framtagande av rengöringutrustning för dränerande beläggningar. Lund: Lunds Tekniska Högskola, Instiutionen för Teknisk Vattenresurslära. Rapport 3149 (in Swedish).

Government of Canada. 2015. Ontario-Kitchener-Waterloo-Barrie: Schedule of Wage Rates. Ottawa: Government of Canada. https://www.canada.ca/en/employment-social-development/programs/government-construction-contracts/ wage-rates/kitchener.html

Hogland, W. and T. Wahlman. 1988. Enhetsöverbyggnad efter några års användning - studier utförda 1986. Lund: Lunds Tekniska Högskola, Instiutionen för Teknisk Vattenresurslära. Rapport 3117 (in Swedish).

ICPI (Interlocking Concrete Pavement Institute). 2006. Permeable Interlocking Concrete Pavements-Design, Specification, Construction, and Maintenance, 3rd ed. Chantilly, VA: Interlocking Concrete Pavement Institute.

ICPI (Interlocking Concrete Pavement Institute). 2009. Permeable Design Pro (Software) for Hydrologic and Structural Design of PICP. Chantilly, VA: Interlocking Concrete Pavement Institute.

James, W. 2004. “Clogging of Permeable Concrete Block Pavement by Street Particulates and Rain." Journal of Water Management Modeling R220-29. https://doi.org/10.14796/JWMM.R220-29

James, W. and C. Gerrits. 2003. “Maintenance of Infiltration in Modular Interlocking Concrete Pavers with External Drainage Cells." Journal of Water Management Modeling R215-22. https://doi.org/10.14796/JWMM.R215-22

James, W. and R. Shahin. 1998. "A Laboratory Examination of Pollutants Leached from Four Different Pavements by Acid Rain." Journal of Water Management Modeling R200-17. https://doi.org/10.14796/JWMM.R200-17

James, W. and B. Verspagen. 1997. "Thermal Enrichment of Stormwater by Urban Pavement." Journal of Water Management Modeling R195-08.

https://doi.org/10.14796/JWMM.R195-08

James, W. and H. von Langsdorff. 2016 "Towards Restoring Infiltration in Permeable Pavers-Initial Demonstration of Rapid Cleanout Concepts." Journal of Water Management Modeling 25:C412. https://doi.org/10.14796/JWMM.C412.

Kresin, C., W. James and D. Elrick. 1997. "Observations of Infiltration Through Clogged Porous Concrete Block Pavers." Journal of Water Management Modeling R195-10. https://doi.org/l 0.14796/JWMM.R195-10 
Lucke, T. and S. Beecham. 2011. “Field Investigation of Clogging in a Permeable Pavement System." Building Research \& Information 39 (6): 603-15. https://doi.org/10.1080/09613218.2011.602182

MPCA (Minnesota Pollution Control Agency). 2017. Minnesota Stormwater Manual. St. Paul, MN: Minnesota Pollution Control Agency.

https://stormwater.pca.state.mn.us/index.php?title=Main_ Page

Myllyoja, R., H. Baroudi, R. E. Pitt and J. Paluzzi. 2001. “Use of SLAMM in Evaluating Best Management Practices." Journal of Water Management Modeling R207-08. https://doi.org/10.14796/JWMM.R207-08

Pezzaniti, D., S. Beecham and J. Kandasamy. 2009. “Influence of Clogging on the Effective Life of Permeable Pavements." Water Management 162 (3): 211-20. https://opus.lib.uts.edu.au/handle/10453/9269

Pitt, R. E., S. Chen, S. Clark, J. Lantrip, C. K. Ong and J. Voorhees. 2003. "Infiltration Through Compacted Urban Soils and Effects on Biofiltration Design." Journal of Water Management Modeling R215-12. https://doi.org/10.14796/JWMM.R215-12

Pitt, R. E. and I. Lantrip. 2000. “Infiltration Through Disturbed Urban Soils." Journal of Water Management Modeling R206-0l. https://doi.org/l 0.14 796/JWMMR206-0I

Pitt, R. E., J. Voorhees and S. Clark. 2011. “Continuous Long Term Simulations for Evaluating Storage Treatment Design Options of Stormwater Filters." Journal of Water Management Modeling R241-07. https://doi.org/10.14796/JWMM.R241-07

Rivard, G., R. Frenette, M. Bolgov and S. Pozgniakov. 2004. “Modeling Surface Runoff, Groundwater Flow and their Interaction with PCSWMM and MODFLOW for the City of Rostov the Great, Russia." Journal of Water Management Modeling R22004. https://doi.org/10.14796/JWMM.R220-04

Rossman, L. A. 2010. “Modeling Low Impact Development Alternatives with SWMM." Journal of Water Management Modeling R236-11. https://doi.org/10.14796/JWMM.R236-11

Sansalone, J., X. Kuang, G. Ying and V. Ranieri. 2012. “Filtration and Clogging of Permeable Pavement Loaded by Urban Drainage." Water Research 46 (20): 6763-74.

Scholz, M. and P. Grabowiecki. 2006. "Review of Permeable Pavement Systems." Building and Environment 42 (11): 3830-6.

Sutherland, R. and S. L. Jelen. 1996. "Sophisticated Stormwater Quality Modeling is Worth the Effort." Journal of Water Management Modeling R191-01. https://doi.org/10.14 796/JWMM.R191-01

Sutherland, R. and S. L. Jelen. 1997. “Contrary to Conventional Wisdom, Street Sweeping Can be an Effective BMP." Journal of Water Management Modeling R195-09. https://doi.org/l 0.14796/JWMM.R195-09

Sutherland, R., S. L. Jelen and G. R. Minton. 1998. "High Efficiency Sweeping as an Altemative to the Use of Wet Vaults for Stormwater Treatment." Journal of Water Management Modeling R200-18.

https://doi.org/10.14796/JWMM.R200-18

Sutherland, R., R. Myllyoja and S. L. Jelen. 2002. "Quantifying the Stormwater Pollutant Reduction Benefits of Traditional Public Works Maintenance Practices." Journal of Water Management Modeling R208-09.

https://doi.org/10.14796/JWMM.R208-09

Tan, S.-A., T.-F. Fwa and C.-T. Han. 2003. "Clogging Evaluation of Permeable Bases." Journal of Transportation Engineering 129 (3): 309-15.

https://doi.org/10.1061/(ASCE)0733-947X(2003)129:3(309)

Thompson, M. K. and W. James. 1995. "Provision of Parking Lot Pavement for Surface Water Pollution Control Studies." Journal of Water Management Modeling R183-24. https://doi.org/10.14796/JWMM.R183-24

Tobin, G. A. and R. Brinkmann. 2002. “The Effectiveness of Street Sweepers in Removing Pollutants from Road Surfaces in Florida." Journal of Environmental Science and Health, Part A 37 (9): 1687-700.

https://doi.org/10.1081/ESE-120015430

TRCA (Toronto and Region Conservation Authority). 2013. Assessment of Life Cycle Costs for Low Impact Development Stormwater Management Practices: Final Report. Toronto: Toronto and Region Conservation Authority.

https://sustainabletechnologies.ca/app/uploads/2013/06/ LID-LCC-final-2013.pdf

UWRC (Urban Water Resources Centre) 2002. Research into "Effective Life" of Permeable Pavement Source Control Installations. Adelaide, SA: University of South Australia. Urban Water Research Centre, Division of IT, Engineering and the Environment. Final Report, Project 07 67680, prepared for Catchment Management Subsidy Scheme.

Vancura, M., K. MacDonald and L. Khazanovich. 2012. “Location and Depth of Pervious Concrete Clogging Material before and after Void Maintenance with Common Municipal Utility Vehicles." Journal of Transportation Engineering 138 (3): 332-8. https://doi.org/10.1061/(ASCE)TE.1943-5436.0000327

Wikipedia. 2018. Street sweeper. https://en.wikipedia.org/wiki/Street_sweeper

Wilson, M. 2002. The Rate of Clogging of Concrete Pavers. Guelph: University of Guelph. MEng project report.

Zhang, G., J. M. Hamlett and T. Saravanapavan. 2010. "Representation of Low Impact Development Scenarios in SWMM." Journal of Water Management Modeling R236-12. https://doi.org/10.14796/JWMM.R236-12 